\title{
EFEKTIVITAS TEKNIK DESENSITISASI SISTEMATIS UNTUK MENGURANGI KECEMASAN BELAJAR SISWA KELAS VIII DI SMP NEGERI 7 TARAKAN TAHUN PELAJARAN 2018/2019
}

\author{
Maya Sandana, Siti Rahmi \\ Fakultas Keguruan dan Ilmu Pendidikan, Universitas Borneo Tarakan \\ Mayasendana99@gmail.com
}

\begin{abstract}
This research aim to to know Effectiveness Technique of Desensitisasi Systematic To Lessen Dread Learn Student Class of VIII In SMP Country 7 Tarakan. Technique of Desensitisasi systematic is an technique to do change tune by focussed aid to client to make calm client of stress by teaching client for rileks in lessening emotional respon which worry. This research use quantitative approach of type of quasi-eksperimen with design group control nonequivalent desain. Research population amount to 230 student. Sampling technique the used is sampling purposive with rule of research sampel and obtained by 20 student which divided in experiment group and control group. used instrument in the form of dread scale learn which have passed test of validasi of judgement expert and expressed is valid.

The mentioned strenghtened with statistical analysis result of calculation of test of ttest by using Statistical Product And Service Solution (SPSS) Version 24.00 windows for obtained nby value of signifikansi $=0.000=0.05$. this matter show value of signifikan less than 0,05 can be pulled [by] conclusion that hypothesis accepted, meaning that technique of desensitisasi effective systematic in lessening dread learn class student of VIII in SMP Country 7 Tarakan School Year $2018 / 2019$.
\end{abstract}

Keyword : Systematic Desensitisasi, Dread Learn.

\section{PENDAHULUAN}

Belajar merupakan hal yang sangat penting untuk dilakukan, segenap kegiatan pendidikan atau kegiatan pembelajaran diarahkan guna mencapai tujuan pembelajaran. Belajar adalah serangkaian kegiatan jiwa raga untuk memperoleh suatu perubahan tingkah laku sebagai hasil pengalaman individu dalam interaksi di lingkungannya yang menyangkut kognitif, afektif, dan psikomotor.

Menurut Djamrah (2015), belajar adalah suatu proses usaha yang dilakukan individu untuk memperoleh suatu perubahan tingkah laku yang baru secara keseluruhan, sebagai hasil pengalaman individu itu sendiri dalam interaksi dengan lingkungannya. Dalam kegiatan pembelajaran di sekolah, kita dihadapkan dengan sejumlah karekteristik siswa yang beraneka ragam. Ada siswa yang dapat menempuh kegiatan belajarnya secara lancar dan berhasil tanpa mengalami kesulitan, namun di sisi lain tidak sedikit pula siswa yang justru dalam belajarnya mengalami berbagai masalah .

Menurut Slameto (2013), bahwa pada tahap ini di mana pekerjaan sekolah paling menantang bagi siswa (tidak terlalu sulit atau terlalu mudah), siswa-siswa dengan tingkat kecemasan yang rendah berprestasi lebih baik dari pada siswa-siswa dengan tingkat kecemasan yang tinggi. Manfaat dari teknik desensitisasi sistematis untuk melemahkan respon terhadap stimulus yang tidak menyenangkan dan mengenalkan stimulus yang berlawanan Dengan pengkondisian klasik respon-respon yang tidak di kehendaki dapat di hilangkan secara bertahap.

Berdasarkan uraian latar belakang diatas, maka penulis tertarik untuk mengkaji lebih dalam mengenai "Efektivitas Teknik Desensitisasi Sistematis Untuk Mengurangi Kecemasan 
Belajar Siswa Kelas VIII Di SMP Negeri 7 Tarakan Tahun Pelajaran 2018/2019.

\section{METODE PENELITIAN}

Jenis penelitian yang digunakan dalam penelitian ini adalah penelitian eksperimen yang bersifat kuantitatif Quasi eksperimental design. Desain eksperimen yang digunakan adalah Control Group Pretest-Postest Design. Menurut Sugiyono (2014), bentuk desain eksperimen ini merupakan pengembangan dari true eksperimental design yang sulit dilaksanakan. Jenis-jenis eksperimen desain berdasarkan baik buruknya eksperimen, atau sempurna tidaknya eksperimen secara garis besar dikelompokkan atas 2 jenis yaitu; Pre Experimental

Design seringkali dipandang sebagai eksperimen yang tidak sebenarnya, disebut demikian karena eksperimen jenis ini belum memenuhi persyaratan seperti cara eksperimen yang dapat dikatakan ilmiah mengikuti peraturanperaturan tertentu. True

Experimental Design yaitu jenisjenis eksperimen yang di anggap sudah baik karena sudah memenuhi persyaratan. Persyataran dalam eksperimen adalah adanya kelompok lain yang tidak di kenal eksperimen dan mendapatkan pengalaman (Arikunto, 2013).

Desain yang digunakan dalam penelitian ini merupakan pengembangan dari true eksperimental design yang sulit dilaksanakan (Sugiyono, 2015). Desain quasi eksperimen digunakan karena pada kenyataannya sulit mendapatkan kelompok kontrol yang digunakan untuk penelitian. Rancangan yan digunakan peneliti adalah nonequivdent control group design, dalam rancangan ini terdapat dua kelompok yaitu kelompok eksperimen dan kelompok kontrol. Kelompok eksperimen diberi pretest dan posttest kemudian akan di bandingkan dengan hasil pretest dan posttest dari kelompok yang tidak diberi perlakuan sebagai kelompok kontrol.

\section{HASIL PENELITIAN DAN PEMBAHASAN}

Penelitian ini dilaksanakan di SMP Negeri 7 Tarakan terhadap 10 siswa pada kelompok eksperimen dan 10 siswa pada kelompok kontrol sebagai subjek penelitian yang diawali dengan pretest dan kemudian diakhiri dengan posttest. Pada kelompok eksperimen siswa diberikan perlakuan dengan teknik desensitisasi sistematis dan pada kelompok kontrol siswa hanya diberikan pretest dan posttest. Adapun pemberian pretest dan post test menggunakan skala dengan tujuan untuk melihat perbandingan sebelum dan setelah pemberian layanan konseling kelompok dengan menggunakan teknik desensitisasi sistematis penelitian ini dilaksanakan di SMP Negeri 7 Tarakan terhitung sejak tanggal 18 juli hingga 9 agustus 2018. Berdasarkan hasil analisis terhadap penelitian yang dilakukan terhadap 10 siswa pada kelompok eksperimen dan 10 siswa pada kelompok kontrol sebagai subjek penelitian, dapat dikatakan bahwa terdapat keterkaitan antara teori dan kenyataan yang terjadi pada saat dilaksanakannya penelitian. Pemberian teknik desensitisasi sistematis diberikan sebanyak lima kali pertemuan sesuai dengan prosedur penelitian eksperimen yaitu melakukan pretest pada sampel sebagai langkah awal untuk mengetahui kecemasan belajar siswa. Kemudian diberikan perlakuan berupa konseling kelompok dengan teknik desensitisasi sistematis dan setelah diberikan perlakuan maka dilakukan posttest. Hal ini dilakukan untuk mengetahui ada tidaknya perbedaan kecemasan belajar siswa sebelum dan setelah diberikan teknik desensitisasi sistematis.

Hasil analisis deskriptif data skala kecemasan belajar siswa menunjukkan bahwa dari keseluruha sampel yang

berjumlah 10 siswa, rata-rata skor kecemasan belajar siswa sebelum diberi perlakuan berada pada kategori tinggi 69.50 dengan skor nilai terendah 64 dan skor nilai tertinggi 75 . Hasil analisis deskriptif data skala kecemasan belajar menunjukkan bahwa dari keseluruhan sampel yang

berjumlah 10 siswa, rata-rata skor kecemasan belajar sesudah diberi perlakuan berada pada kategori rendah yaitu 57.10 dengan skor nilai terendah 54 dan skor tertinggi 59.

Hasil perbandingan menunjukkan terdapat perbedaan yang signifikan dari sebelum dan setelah diberikan traetment 
menggunakan teknik desensitisasi sistematis. Ini terlihat dari perbedaan nilai kecemasan dan perubahan perilaku yang ditujukkan oleh subjek dari sebelum dan setelah diberikan treatment. Diperoleh data skor peraspek yaitu pada aspek tidak percaya diri, selalu gelisah dan tidak bisa berkonsentrasi sebelum diberikan perlakuan (pretest) berada dalam kategori tinggi. Adapun setelah siswa diberikan perlakuan (posttest) maka diperoleh data skor per-aspek tidak percaya diri, selalu gelisah dan tidak bisa berkonsentrasi berada dalam kategori rendah.

Penelitian yang dilakuakn oleh Tya Anggreini, (2012) pada aspek tidak bisa berkonsentrasi calon mahasiswa

dalam menghadapi tes SBMPTN sebelum diperikan treatment dengan teknik desensitisasi sistematis aspek tersebut masuk dalam kategori tinggi. Pada saat diberikan treatment dengan teknik desensistisasi sistematis kecemasan belajar siswa pada aspek tidak bisa berkonsentrasi masuk dalam kategori rendah. Jadi dapat dikatakan bahwa teknik desensitisasi sistematis efektif untuk mengurangi kecemasan belajar siswa.

Willis (2013), Menurut pendekatan konseling behavioral, suatu kecemasan diperoleh seseorang melalui belajar dalam kondisi tertentu. Oleh karena itu, untuk mengurangi atau menurunkan kecemasan harus melalui usaha yang dikondisikan pula sehingga kecemasan itu berakhir yaitu dengan menggunakan teknik desensitisasi sistematis. Seperti halnya yang dikatakan Komalasari (2011), teknik desensitiasi sistematis digunakan untuk menghapus cemas dengan tingkah laku menghindar. Desensitiasi sistematis dilakukan dengan menerapkan pengkondisian klasik yaitu dengan melemahkan kekuatan stimulus penghasil kecemasan, gejala kecemasan bisa dikendalikan dan dihapus melalui penggantian stimulus dan menurut.

Pada penelitian ini teknik desensitisasi dikatakan efektif untuk mengurangi kecemasan belajar siswa. Penelitian Tya Anggreini (2012), bahwa penelitian ini dilakukan untuk melihat penggunaan teknik desensitisasi sistematis untuk mengurangi kecemasan calon mahasiswa dalam menghadapi tes SBMPTN. Kesimpulan dalam penelitian ini adalah penggunaan teknik desensitisasi sistematis dapat mengurangi kecemasan calon mahasiswa dalam menghadapi tes SBMPTN. Perbedaan penelitian peneliti dengan Tya Anggreini (2012), adalah untuk melihat penggunaan teknik desensitisasi sistematis untuk mengurangi kecemasan calon mahasiswa dalam menghadapi tes SBMPTN teknik pengumpulan data penelitian ini menggunakan angket tertutup, validitas dalam penelitian ini adalah validitas isi (Content Validity).

Penelitian peneliti berjudul efektivitas teknik desensitisasi sistematis untuk mengurangi kecemasan belajar siswa kelas VIII di SMP Negeri 7 Tarakan tahun pelajaran 2018/2019. Penelitian ini bertujuan untuk melihat efektivitas dari teknik desensitisasi sistematis teknik pengumpulan data dalam penelitian ini menggunakan skala likert validitas dalam penelitian adalah uji validitas internal dengan menggunakan analisis butir.

\section{DAFTAR PUSTAKA}

Arikunto, S. (2013). Prosedur Penelitian: Suatu Pendekatan Praktik Jakarta: Rineka .Cipta

Abimanyu, Soli \& Manrihu. (1996). Teknik dan Laboratorium Konseling. Jakarta: Proyek Pendidikan Tenaga Akademik Departemen Pendidikan dan Kebudayaan.

Corey, Gerald. (2013). Teori dan Praktek Konseling dan Psikoterapi, Refika Aditama.

Danim, Sudarwan. (2010). Perkembangan Peserta Didik, Bandung: Alfabeta.

Djamarah, Bahri, Syaiful. (2015). Psikologi Belajar. Jakarta: Reneka Cipta.

Davidoff, L. (1991). Psikologi Suatu Pengantar Edisi Ke Dua Jilid 2. Jakarta: Erlangga.

Erford, T. Bradley (2010). 40 Teknik Yang Harus Diketahui Setiap Konselor, Penata .Aksasara.

Ghufron Nur, M. Risnawati Rini, S. (2017). Teori-Teori Psikologi. Jakarta: ArRuzz Media.

Komalasari, Wahyuni \& Karsih.2016. Teori Dan Teknik Konseling. Jakarta:Indeks.

Kurtanto , M. Edi. (2013). Konseling Kelompok. Bandung : Alfabeta. 
Prayitno. 2012. Seri Panduan Layanan dan Kegiatan Pendukung

Konseling. Padang: Universitas Negeri Padang.

Lestarai, Tri, Puji. (2016). Pengaruh Teknik Desensitisasi Sistematis Terhadap Kecemasan Berbicara Di Depan Kelas Siswa Kelas XI SD MAN Tarakan Tahun Pelajaran 2016/2017. Skripsi: Tidak di terbitkan. Universitas Borneo Tarakan.

Syah, Muhibbin. (2014). Psikologi Pendidikan. Bandung: Remaja Rosdakarya.

Slameto. (2013). Belajar dan FaktorFaktor yang Mempengaruhinya. Jakarta: Rineka Cipta.

Sudrajat, Akhmad. (2011). Masalah Siswa Melalui Konseling Layanan Konseling Individual. Yogyakarta : Paramitra Publishing.

Suardana, Putri \& Simarmata Nicholas. (2013). Hubungan Antara Motivasi Belajar dan Kecemasan pada Siwa V Sekolah Dasar di Denpasar

Menjelang Ujian Nasional. Jurnal Psikologi Undayan. ( 1(1) 203212).

Sugiyono, (2015). Metode Penelitian Pendidikan Pendekatan

Kuantitatif Kualitatif dan

R\&D.Bandung:ALFABETA

Ulfa, Maria. (2015), Beragam

Gangguan Paling Sering

Menyerang

Anak. Yogyakarta:.FlashBooks

Widjaya, Hendra. (2016). Berani tampil beda dan percaya diri. Araska Publisher.

Willis, Sofyan.(2004). Konseling Individual Teori dan Praktek. Bandung: Alfabeta.

Yanti Supri, Erlamsyah, \& Zikra. (2013). Hubungan Antara Kecemasan dalam Belajar Dengan Motivasi Belajar, Jurnal Ilmiah Konseling (Volume 2 (1) : 283-288) 